\title{
Relawan Abdimas STIKES Pemkab Jombang Dalam Percepatan Vaksinasi Covid-19 di Wilayah Kerja Puskesmas Cukir Kabupaten Jombang
}

\author{
Niken Grah Prihartanti ${ }^{*}$, Rani Yujiani ${ }^{2}$, Cintana Pritviatana Kusuma Wardani ${ }^{3}$, Siti Muniroh ${ }^{4}$ \\ Aulia Reza Marcelina ${ }^{5}$, Putri Lailatul Arifah ${ }^{6}$, Rara Roro Retno Ayu Ericha Kurniawati ${ }^{7}$ \\ 1*,7Program Studi Sarjana Kebidanan Stikes Pemkab Jombang \\ 2,3,4,5,6Program Studi Diploma III Kebidanan Stikes Pemkab Jombang \\ e-mail: nikengrah01@gmail.com \\ *Penulis Korespondensi: E-mail: nikengrah01@gmail.com
}

\begin{abstract}
The condition of the COVID-19 pandemic, which has not yet ended and the rapid spread of it, requires efforts to deal with it. In addition to implementing strict health protocols, one other very possible way to prevent the spread of this virus is by vaccination. In this regard, community service is driven by lecturers to Midwifery students from STIKES PEMKAB JOMBANG who are willing to help Covid19 vaccinator officers. Community service aims to get students involved as vaccinators and contribute directly to efforts to accelerate Covid19 vaccination. The subjects of this activity are all people with criteria of age more than 18 years and have no history of comorbidities. The vaccination activity took place at the village hall of the Cukir Health Center area. Among them are the village halls of Grogol, Puton, and Bandung. Every day before the activity starts, students will be briefed first and then assigned to help the vaccinator at the screening table to check blood pressure and body temperature and act as a vaccinator. It is hoped that similar community services can be carried out in various regions so that the contribution of health students during the pandemic can be implemented. Synergy between students, the community, academics, and the government is very much needed so that this COVID-19 pandemic ends soon.
\end{abstract}

Keywords: Covid-19, Vaccination, Community service

\begin{abstract}
Abstrak
Kondisi pandemi covid-19 yang belum berakhir dan pesatnya penyebarannya perlu melakukan upaya-upaya dalam menanganinya. Selain menerapkan protokol kesehatan yang ketat, salah satu cara lain yang sangat mungkin untuk mencegah penyebaran virus ini adalah dengan melakukan vaksinasi. Sehubungan itu maka pengabdian kepada masyarakat digerakkan dosen pada mahasiswa Kebidanan STIKES PEMKAB JOMBANG yang bersedia untuk membantu petugas vaksinator Covid19. Pengabdian masyarakat bertujuan agar mahasiswa ikut terlibat sebagai vaksinator dan berkontribusi secara langsung dalam upaya percepatan vaksinasi Covid19. Subjek kegiatan ini yaitu semua masyarakat dengan kriteria usia lebih dari 18 tahun dan tidak memiliki riwayat penyakit penyerta. Kegiatan vaksinasi bertempat di balai desa wilayah Puskesmas Cukir. Diantaranya di balai desa Grogol, Puton, dan Bandung. Setiap harinya sebelum kegiatan dimulai mahasiswa akan mendapat pengarahan dulu kemudian ditugaskan untuk membantu vaksinator di meja skrining untuk melakukan pengecekan tekanan darah dan suhu tubuh serta bertindak sebagai tenaga vaksinator. Diharapakan pengabdian masyarakat serupa dapat dijalankan di berbagai wilayah sehingga kontribusi mahasiswa kesehatan dalam masa pandemi dapat diimplementasikan. Sinergi antara mahasiswa, masyarakat, akademisi, dan pemerintah sangat diperlukan agar pandemi covid-19 ini segera berakhir.
\end{abstract}

Kata kunci: Covid 19, Vaksinasi, Pengabdian Masyarakat

\section{PENDAHULUAN}

Pemerintah telah menetapkan pandemi Corona Virus Disease 2019 (COVID-19) sebagai bencana non-alam. Sejak diumumkannya kasus konfirmasi pertama pada Maret 
2020, dalam rentang waktu satu bulan, seluruh provinsi telah melaporkan kasus konfirmasi. Penyebaran COVID-19 tidak hanya terjadi di kota besar dan kota padat penduduk lainnya, namun telah menyebar hingga ke pedesaan di daerah terpencil (KEPDIRJEN Pencegahan Dan Pengendalian Penyakit Nomor HK.02.02/4/1/2021). Sampai dengan tanggal 16 Juli 2021, sebanyak 2.780.803 kasus konfimasi COVID-19 telah dilaporkan di Indonesia dan tercatat sejumlah 71.397 orang meninggal. Sedangkan di Kabupaten Jombang saat ini per tanggal 16 Juli 2021, sebanyak 6704 kasus konfimasi COVID-19 dan tercatat sejumlah 797 orang meninggal.

Pandemi COVID-19 telah berdampak merugikan masyarakat, tidak hanya kesakitan dan kematian tetapi juga pada berbagai bidang sosial dan ekonomi. Efek pandemi dengan berbagai situasi yang berhubungan seperti pembatasan kegiatan, pembatasan perdagangan, pembatasan pergerakan, dan penguncian daerah menyebabkan terbatasnya kegiatan berbagai sektor produksi. Intervensi bidang kesehatan diawali dengan Pembatasan Sosial Berskala Besar dan pendidikan publik untuk mematuhi protokol kesehatan, diikuti gerak cepat pemerintah Indonesia untuk melaksanakan program vaksinasi COVID-19 secara nasional.

Sementara itu, tingkat kerentanan masyarakat semakin meningkat yang disebabkan kurangnya kesadaran masyarakat terhadap penerapan protokol kesehatan seperti memakai masker, mencuci tangan dan menjaga jarak minimal - 2 meter. Tanpa intervensi kesehatan masyarakat yang cepat dan tepat, diperkirakan sebanyak 2,5 juta kasus COVID19 akan memerlukan perawatan di rumah sakit di Indonesia dengan angka kematian yang diperkirakan mencapai 250.000 kematian. Oleh karena itu, perlu segera dilakukan intervensi tidak hanya dari sisi penerapan protokol kesehatan namun juga diperlukan intervensi lain yang efektif untuk memutuskan mata rantai penularan penyakit, yaitu melalui upaya vaksinasi (KEPDIRJEN Pencegahan Dan Pengendalian Penyakit Nomor HK.02.02/4/1/2021).

Vaksinasi COVID-19 bertujuan untuk mengurangi transmisi penularan COVID-19, menurunkan angka kesakitan dan kematian akibat COVID-19, mencapai kekebalan kelompok di masyarakat (herd immunity) dan melindungi masyarakat dari COVID-19 agar tetap produktif secara sosial dan ekonomi. Pelayanan vaksinasi COVID-19 dilaksanakan dengan tetap menerapkan protokol kesehatan yaitu dengan menerapkan upaya Pencegahan dan Pengendalian Infeksi (PPI) dan menjaga jarak aman 1 - 2 meter, sesuai dengan Petunjuk Teknis Pelayanan Vaksinasi Pada Masa Pandemi COVID-19.

Pengabdian masyarakat yang dilakukan oleh relawan Abdimas Stikes Pemkab Jombang ini memiliki tujuan yaitu untuk membantu percepatan vaksinasi di seluruh wilayah di Kabupaten Jombang khususnya vaksinasi pada masyarakat cakupan wilayah puskesmas Cukir. Mengingat saat ini hampir seluruh wilayah di Jombang menjadi zona merah karena penyebaran Covid 19 yang begitu pesat. Selain mematuhi protokol kesehatan yang ada, sangat diperlukan dilakukan vaksinasi sebagai upaya pencegahan dan pengendalian covid 19 yang dapat memberikan perlindungan bagi masyarakat agar terhindar penularan dari Covid 19.

\section{METODE PELAKSANAAN}

Kegiatan pengabdian masyarakat oleh relawan Abdimas Stikes Pemkab Jombang melalui kegiatan vaksinasi di wilayah cakupan Puskesmas Cukir ini dilakukan selama tiga hari di tiga tempat yang berbeda. Pada hari pertama kegiatan pengabdian masyarakat vaksinasi dilakukan di Balai desa Grogol Kecamatan Cukir dengan sasaran vaksinasi sebanyak 500 orang. Pada hari kedua kegiatan pengabdian masyarakat vaksinasi dilakukan di Balai desa Puton Kecamatan Cukir dengan sasaran vaksinasi sebanyak 550 orang. Pada hari ketiga kegiatan pengabdian masyarakat vaksinasi dilakukan di Balai desa Bandung 
Kecamatan Diwek dengan sasaran vaksinasi sebanyak 500 orang. Pelaksanaan Vaksinasi di balai desa tersebut mahasiswa didampingi oleh petugas kesehatan dari Puskesmas Cukir. Relawan Abdimas dari Stikes Pemkab Jombang diberikan kesempatan untuk melakukan skrining dan pemeriksaan tekanan darah, suhu pada calon peserta yang akan di vaksin, dan sebagai vaksinator. Alur kegiatan vaksinasi dimulai dari masyarakat datang ke balai desa untuk melakukan vaksin mendaftarkan diri terlebih dahulu ke bagian administrasi pendaftaran dengan membawa persyaratan untuk vaksin seperti membawa salinan KK dan KTP. Selanjutnya peserta vaksin tersebut dilakukan skrining melalui pengukuran tekanan darah dan suhu oleh mahasiswa Stikes Pemkab didampingi petugas kesehatan Puskesmas Cukir. Kemudian jika kondisi peserta vaksin dalam kondisi baik dan memenuhi kriteria diperbolehkan vaksin, peserta vaksin selanjutnya dilakukan injeksi vaksin oleh petugas kesehatan dari Puskesmas Cukir. Setelah di vaksin peserta vaksin dapat menunggu terlebih dahulu untuk mendapat kartu vaksin. Masyarakat tampak antusias mengikuti kegiatan vaksinasi.



Gambar 1. Proses Pelaksanaan Kegiatan Skrinning Vaksinasi di Balai Desa Puton (Sumber: Relawan Abdimas Stikes Pemkab Jombang)

\section{HASIL dan PEMBAHASAN}

Kegiatan pengabdian masyarakat oleh abdimas Stikes Pemkab Jombang yang terdiri dari 6 orang mahasiswa kebidanan dengan 1 orang dosen kebidanan ditugaskan untuk membantu kegiatan vaksinasi wilayah cakupan Puskesmas Cukir. Didampingi oleh petugas kesehatan Puskesmas Cukir, kegiatan pengabdian masyarakat vaksinasi dilakukan mahasiswa selama 3 hari di tempat yang berbeda.

Tabel 1. Kegiatan Pengabdian Masyarakat Program Percepatan Vaksinasi di Puskesmas Cukir

\begin{tabular}{cccc}
\hline No & Waktu & Lokasi & Capaian \\
\hline 1. & Rabu, & $\begin{array}{c}\text { Balai Desa Grogol } \\
\text { Kecamatan Cukir }\end{array}$ & $\begin{array}{c}\text { Vaksinasi } \\
\text { masyarakat dengan } \\
\text { sasaran 500 orang }\end{array}$ \\
07 Juli 2021 & Balai Desa Puton & $\begin{array}{c}\text { Vaksinasi } \\
\text { Kasyarakat dengan } \\
\text { sasaran 550 orang }\end{array}$ \\
Kamis, & K8 Juli 2021 & Balai Desa Bandung & $\begin{array}{c}\text { Vaksinasi } \\
\text { masyarakat dengan } \\
\text { sasaran 500 orang }\end{array}$ \\
\hline
\end{tabular}

(Sumber: Relawan Abdimas Stikes Pemkab Jombang) 
Masyarakat sangat antusias datang ke balai desa tempat dilaksanakannya vaksinasi. Dalam melakukan kegiatan pengabdian masyarakat ini, tim relawan Abdimas menggunakan APD level 2. Langkah awal dilaksanakan kegiatan pengabdian masyarakat ini peserta vaksin mendaftarkan diri ke bagian pendaftaran terlebih dahulu, selanjutnya peserta vaksin dilakukan skrining pemeriksaan tekanan darah dan suhu tubuh oleh relawan abdimas dari Stikes Pemkab dengan di dampingi dan dibimbing oleh ibu dan bapak petugas kesehatan dari Puskesmas Cukir. Skrining dilakukan dengan teknik wawancara dengan memberikan pertanyaan seputar riwayat dan keadaan calon peserta vaksin saat itu. Banyak dari masyarakat yang harus pulang karena belum memenuhi persyaratan untuk dilakukan vaksinasi, seperti saat di lakukan pemeriksaan Tekanan Darah sistole diatas $180 \mathrm{mmHg}$, pernah mengalami serangan jantung, memiliki riwayat epilepsi, atau memiliki penyakit penyerta lainnya. Bagi peserta vaksin yang sudah memenuhi persyaratan setelah di skrining dan kondisinya baik untuk di vaksin, peserta vaksin dapat segera dilakukan vaksinasi yang dilakukan oleh petugas kesehatan dari Puskesmas Cukir. Setelah selesai tindakan vaksinasi, peserta vaksin dianjurkan untuk diobservasi selama 30 menit untuk memantau ada tidaknya efek samping yang timbul pasca penyuntikkan sembari menunggu kartu vaksin. Setelah semua tahapan setelah dilakukan vaksinasi peserta vaksin dianjurkan untuk segera pulang ke rumah untuk menghindari kerumunan.

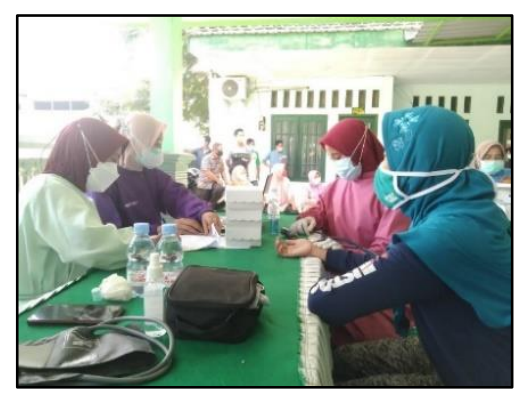

Gambar 2. Proses Pelaksanaan Kegiatan Vaksinasi di Balai Desa Bandung (Sumber: Relawan Abdimas Stikes Pemkab Jombang)

Kegiatan pengabdian masyarakat ini tentu bermanfaat bagi masyarakat sebagai perwujudan upaya percepatan vaksinasi ini di wilayah kerja Kabupaten Jombang. Kegiatan ini juga memiliki manfaat bagi relawan Abdimas Stikes Pemkab Jombang dalam mengimplementasikan pengabdian tenaga kesehatan dimasa pandemi ini. Mahasiswa dapat menambah wawasan ilmu, mendapat pengalaman yang luar biasa yang mungkin belum di dapatkan sebelumnya, mengasah kemampuan berkomunikasi, menerapkan dan melatih kemampuan dari hasil perkuliahan, dapat mengenal dan mempelajari lingkungan masyarakat yang lebih luas, serta dapat ikut serta dalam memutus rantai penyebaran Covid 19.

\section{KESIMPULAN}

Kegiatan Pengabdian Masyarakat oleh Abdimas Stikes Pemkab sebagai vaksinator di wilayah Puskesmas Cukir Kabupaten Jombang dilakukan dalam waktu 3 hari dengan jumlah sasaran 1550 orang. Kolaborasi Abdimas Stikes Pemkab Jombang dengan tenaga medis di Puskesmas terjalin dengan baik, dengan indikator pelaksanaan kegiatan berjalan lancer dan tertib. Rangkaian prosedur kegiatan vaksinasi sebagai upaya percepatan vaksin covid-19 berjalan sesuai prosedur. Target capaian vaksinasi di wilayah Puskesmas Cukir tercapai $89 \%$ dikarenakan sebanyak 170 orang atau sebesar $11 \%$ tidak memenuhi syarat untuk dilakukan Tindakan vaksin Covid-19. 


\section{UCAPAN TERIMAKASIH}

Penulis mengucapkan terima kasih kepada Program Studi Diploma III Kebidanan dan Sarjana Kebidanan Stikes Pemkab Jombang, yang telah memfasilitasi dalam penyediaan APD. Penulis juga mengucapkan terima aksih kepada para petugas kesehatan puskesmas Cukir yang telah memberikan kesempatan untuk ikut terlibat dalam kegiatan percepatan vaksinasi Covid19. Tidak lupa penulis juga mberterima kasih kepada masyarakat yang ikut serta dalam kegiatan vaksinasi yang telah kooperatif dalam pelaksanaan kegiatan pengabdian masyarakat ini.

\section{DAFTAR PUSTAKA}

Jayani, I., \& Ramayanti, E. D. (2021). Edukasi Penerapan Protokol Kesehatan Pada Era New Normal Sebagai Bentuk Upaya Pencegahan Pengendalian Covid-19. 5(1), 1-8.

KEMENKES RI DIREKTORAT JENDERAL Pencegahan dan Pengendalian Penyakit, Keputusan Direktur Jenderal Pencegahan Dan Pengendalian Penyakit Nomor HK.02.02/4/1/2021 Tentang Petunjuk Teknis Pelaksanaan Vaksinasi Dalam Rangka Penanggulangan Pandemi Corona Disease (Covid 19), Direktur Jenderal Pencegahan Dan Pengendalian Penyakit, Jakarta

Mansyur, M. (2021). Vaksinasi COVID-19 bagi Pekerja, Harapan Pulihnya Produktivitas. 1-4.

Publicuho, J., Virdani, D., Kasih, K. D., \& Arif, L. (2021). IMPLEMENTASI KEBIJAKAN VAKSINASI COVID-19. 4(2), 501-510. https://doi.org/10.35817/jpu.v4i2.18061

Rahman, Y. A. (2021). Vaksinasi Massal Covid-19 sebagai Sebuah Upaya Masyarakat dalam Melaksanakan Kepatuhan Hukum ( Obedience Law ). 3(2), 80-86. https://doi.org/10.15575/kh.v3i2.

Ritunga, I., Lestari, S. H., Santoso, J. L., Effendy, L. V., Charles, S., Tua, P., Lindarto, W. W., \& Nurhadi, S. (2021). Penguatan Program Vaksinasi Covid-19 Di Wilayah Puskesmas Made Surabaya Barat. 5(1), 45-52. 